\title{
FENOMENUL TEATRAL CA PROCES CONTINUU DE TRANSFORMARE ȘI EXTINDERE ${ }^{1}$
}

drd. arh. Silvia Ionescu

Universitatea de Arhitectură și Urbanism "Ion Mincu"

gogoasa.diana.arh@gmail.com

\section{Rezumat}

Fenomenul teatral a evoluat continuu adaptându-se cerințelor fiecarei perioade istorice, fiind totodata un mijloc de propagare a valorilor acesteia.

În contextul social actual, de perpetuă schimbare și adaptare la suflul nou, teatrul are rolul semnificativ de a propaga deziderate conceptuale, menite a fi model pentru o societate dezorientată aflată mereu în căutarea identității. Astăzi rolul de simplu privitor este abolit, mizându-se tot mai mult pe un teatru viu ce emană emoţie, trăieşte împreună cu publicul său, nu doar pentru public.

Spectacolul se schimbă și odată cu el şi spaţiul. Evoluţia conceptului de spectacol, atrage după sine schimbarea spaţiului. Desacralizarea teatrului şi aducerea spectatorilor, în diferite spaţii urbane neteatrale, oferă creatorilor de teatru experimental noi forme de expresie Astfel un teatru viu care se simte, se vede, se aude, având o semnificaţie cu precădere senzorială iși găsește puterea de a propaga valori artistice în contextul social actual, fiind totodata un mijloc de propagare a volorilor acesteia.

Cuvinte cheie: teatrul neconvențional, spații teatrale, spații teatrale alternative, teatrul experimental

${ }^{1}$ Articol extras din teza de doctorat, nepublicată: Teatrul neconvențional, Relația spațiu, tehnologie, spectacol. Coordonator stiințific prof. dr. arh. Emil Barbu Popescu. 


\section{Introducere}

Spectacolul se schimbă și odată cu el şi spaţiul. Arhiectura clasică a teatrelor, nu mai corespunde cerinţelor noului val de regizori. Evoluţia conceptului de spectacol, atrage după sine schimbarea spaţiului, spre unul dinamic, uşor transformabil pentru a oferi opţiuni variate.

Teatrul, ca organism viu, nu poate fi oprit şi canonizat, el a evoluat continuu adaptându-se cerințelor fiecarei periode istorice, fiind totodata un mijloc de propagare a volorilor acesteia. Fenomenul teatral văzut ca simbioză între spațiu arhitectural și spectacol are nevoie mereu de suflu nou, fiind într-un proces perpetuu de transformare și extindere.

Aşa cum relatează Peter Sellars, spectacolul de teatru este un atribut al prezentului, având puterea de a influența publicul de a transmite valorile și desideratele culturale actuale unei societăți dezorientate ce nu-și mai găseste identitatea fiind mai degrabă atrasă de devertismentul accesibil, comercial. Acestea sunt premisele actuale,

"Teatrul dispune de un sens al timpului, acesta e prezentul. E momentul actual, dintre noi. E momentul în care eu sunt aici, dumneavoastră acolo. E un moment pe care nu-l putem repeta. E întotdeauna un moment exact, precis. Teatrul nu poate crea decât prezentul. Dar interesant este faptul că el vorbește despre trecut în prezent." (Toniza 2004, 538)

Asumându-ne aceste premize, teatrul creat acum şi aici, adoptă suflul nou, neconvenţional, inoculat de viziunile actuale ale creatorilor de teatru, care îşi doresc să scape de rigiditatea spaţiilor clasice, convenţionale și să pătrundă în viața cotidiană a publicului.

Desacralizarea teatrului şi aducerea spectatorilor, în diferite spaţii urbane neteatrale, oferă creatorilor de teatru experimental, percepţii diferite, facându-i să viseze la noi forme de expresie Astfel un teatrul viu care se simte, se vede, se aude, având o semnificaţie cu precădere senzorială iși găsește puterea de a propaga valori artistice în contextual social actual.

Teatrul nu mai depinde de un loc anume, el poate fi reprezentat oriunde, pe stradă, în cafenele, în spaţii abandonate, tot ce contează este legătura dintre spectacol şi spectator, privitorul devine parte integrală a actului creator.

Limitând discuția la niveul artei teatrale experimentale, spectacolul nu poate fi separat de spaţiu şi invers, au trăit, au evolut şi s-au reinventat împreună, de-a lungul istoriei. Având ca premisă această relaţie indestructibilă, fiind o reflexie a societații jucând rolul de a propaga valorile specifice fiecărei periode istorice și totodată de a manipula, masele.

În contextul social actual, de perpetuă schimbare și adaptare la suflul nou, teatrul are rolul semnificativ de a propaga deziderate conceptuale, menite a fi model pentru o societate dezorientată aflată mereu în căutarea identității/echilibrului. Astăzi rolul de simplu privitor este abolit, mizându-se tot mai mult pe un teatru viu ce emană emoţie, trăieşte împreună cu publicul său, nu doar pentru public.

\section{Evoluția fenomenului teatral în secolele XX, XXI}

Imaginea teatrului cunoscut de noi, se conturează în secolul al XVIII-lea. Putem vorbi în sfârşit de începuturile regiei moderne, prin Școala din Meiningen din Germania. Teatrul din Meiningen renunță la convenționala scenă deschisă, preferând scena închisă, realistă cu cadru 
de interior. De asemenea, înlocuiește decorurile bidimensionale pictate, cu decoruri construite tridimensional, pentru ca iluzia realității să fie mai ușor acceptată de spectator.

Secolul al XX-lea este tumultuos pentru arta teatrului, numeroșii regizori abordează noi forme de expresie, pentru a aduce mereu ceva nou. Nu mai puțin diverse sunt și soluțiile date de problema amenajării scenei, de la păstrarea în linii mari, a tipului clasic de configurare, publicul poziționat în fața scenei, dar cu sensibile modificări cum ar fi abolirea rampei, avanscena laterală și posibilitatea de a reduce deschiderea scenei, la căutarea unor noi structuri scenice care să realizeze o apropiere fizică cu actorul.

Începutul secolului XX aduce shimbări în modul de perceție a teatrului. Acesta trece de la divertismentul siropos al secolului XIX la realismul dramatic prezentând imaginea necenzurată a societății. Tinerii dramaturgi și regizorii migrează spre spații alternative, improvizate unde pot să-și prezinte liber creațiile. Noul teatru marcat de realismul scenic și trecerea de la decorul pictat la cel construit este legat de inființarea companiei Theatre Libre coordonată de Andre Atoine, adept al naturalismului scenic.

Abordarile scenice naturaliste s-au perpetuat cu rapiditate la nivelul întregii Europe. Însă apogeul naturalismului scenic îl atinge Konstantin Stanislavski reușind să surprindă patina timpului, ambientul denotat de statutul social și inclusiv mirosul, astfel scenografia atinge noi valențe senzoriale, tablou completat de realismul din dramaturgia lui Anton Cehov.

Un secol al controverselor al negării și renașterii conceptuale, în scurt timp naturalismul scenic este blamat iar cei mai radicali exponenți împotriva imaginii scenice ce reproduce fotografic realitatea sunt Gordon Craig și Adolf Appia care esențializează arta teatrală atât la nivel scenografic cât și regizoral. Abstractizează decorul rezumându-I la câteva elemente arhitecturale, trepte, coloane, un joc grafic care este accentuat de virulența luminii .

Primul Război Mondial transformă teatrul într-un strigăt contestatar împotriva indeologiilor probagate. Apogeul spectacolelor teatrale ce au ca scop protestul este atins de teatrul dadaist cu ai să-i reprezentanți Tristan Tzara, Hugo Ball și Emmy Hennigs care au fondat în 1916 la Zurich Cabaret Voltare. Profitând de statul neutru al Elveției, ies în evidență prin spectacolele violente și haotice, unde muzica dansul și poezia sunt reprezentante concomitent într-un strigăt disperat împotriva ororilor războiului.

Imaginea societății s-a reflectat mereu în teatru. Sfarșitul Primului Razboi Mondial aduce lozinci precum Teatrul e o armă, insuși Vsevolod Meyerhold propaga lozinca Auceți la Teatru Revoluția din Octombrie. Devenid o arma, un mod de a esentializa trairile unei națiuni,teatrul devine o arma modelatoare a maselor.

La nivel vizual, scenografic, Vsevolod Meyerhold expune desavârșit ideologiile și simbolistica decostructivismului rus. În abordările sale scenice propune un spațiu eviscerat, desființează cadrul scenei și proscena lansând la vedere pereții goi din cărămidă și propune o scenografie creată din platforme pe mai multe nivele, scari, rampe, roții, ce sunt suport pentru spațiul de acțiune unde actorul este transfigurat într-o marionetă bio-mecanică.

Agitația politică mondială continuă odata cu Al Doilea Razboi Mondia aducând cooperarea în rândul teatrelor independente din Germania și Italia care orgazează mici reprezentații pe front pentru a distra trupele.

Sfârșitul Războiului lasă cicatrici, publicul empatizează cu spectacole de divertisment, siropoase, musical, spectacolele de pe Broadway au un mare succes. Dar costurile din ce în ce 
mai ridicate ale producțiilor și suvențiile acordate teatrelor din provincie, în Statele Unite, Anglia si Germania, transformă spații precum o piața de bumbac din Manchester în Royal Theatre, ce are o structură atipică, un cub din sticlă așezat pe patru stâlpi. Un alt exeplu este Alley Theatre ce își desfășoară activitatea într-o fosta fabrică de evantaie din Hustan. Astfel micile trupe migrează spre spații alterative atragând publicul.

Ani 70 aduc criza financiară în rândul teatrelor, care deși suvenționate se confruntă cu lipsa publicului situație delicată fiind amplificată și de costurile mari ale producțiilor. În acest context defavorabil teatrele din Europa găzduiesc proiecte independente, experimentale reușind să atragă un pubilic nou, însetat să experimenteze noi forme de expresie.

\section{Spațiul teatral văzut din prisma regizorilor}

Bazele teoretice și conceptuale ale noului teatru sunt conturate, toreticieni și regizori schițează imaginea teatrului ideal unde pot să-și etaleze fără constrângeri creațiile.

Antonue Artaud vede posibilă o renaştere a teatrului, prin eliminarea convenţionalităţii limbajului, esențializând spectacolul la o formă strict vizuală. El consideră că teatrul și-a pierdut atractivitatea, elitele nemaigâsind stimulul provocator, renunţă la el, iar masele işi caută satisfacţii imediate, cu un mesaj facil, în locuri accesibile precum sala de cinema, music-hall, sau circ. Teoriile sale legate de arta teatrului propun, un spectacol credibil, realist, viu, atragător, asftel publicul "va crede în visele teatrului" (Toniza 2004, 304). Se face apel la un spectacol total, care exploatează la maxim sensibilitatea noastră senzorială prin sunet, ritm, imagine, comasat înt-un act artistic unitar.

Pornind de la spectacolul total, ce iși are rădăcinile pe o experiență comună, act artistic, privitor, Jerzy Grotowski s-a concentrat în demersurile sale teoretice asupra relaţiei spectacolspectator. El nu vede teatrul, ca pe o satisfacere imediată a nevoilor culturale și nici ca pe un mod de divertisment facil. Teatrul e mai mult, e apanajul spectatorului a cărui "nelinişte nu este generală, ci îndreptată în sensul căutării adevărului despre sine însuşi şi despre viziunea lui în viaţă." Toniza 2004, 209). Mizând pe un spectacol care să incite emoțional și intelectual spectatorul, un act artistic cu rol inițiatic pentru publicul său.

Tot Grotowski vorbeşte despre teatru ca loc de întâlnire al creatorilor şi artelor. Preocuparile sale spațiale trec granițele spectacolului și ajung și în sfera arhitecturii, fiind preocupat inclusiv de modul de dispunere al scaunelelor spectatorilor, doar printr-o simbioză perfectă se poate crea un act cu adevărat emoţionant și valoros.

Peter Brook cu a sa lucrare Spaţiul gol, demontează teatrul tradiţonal atât ca spaţiu cât şi ca abordare regizorală. Mizând pe latura brutală a teatrului şi considerând că acesta se poate face oriunde, pe stradă, în hambare, în mansarde, tot ceea ce contează este contactul, interacțiunea cu publicul, acesta forță fiind definitorie pentru arta spectacolului.

“Pot să iau orice spaţiu gol şi să-I consider o scenă. Un om traversează acest spaţiu gol, şi altul îl priveşte şi e tot ce trebuie să aibă un act teatral." (Brook, 2014, prefaţă)

Brook are puterea de a metamorfoza orice spațiu urban fie el public sau privat într-un spațiu teatral, mizâd pe efemeritatea timpului și variatatea arhitecturală esențializează aceste doua elemente inseparabile, spațiul și spectacolul, într-un act de creație total ce înglobează într-un 
întreg privitorul și creatorul. El vine în întâmpinarea noului public căutând neîncetat spațiul ideal pentru a fi cadrul noului teatru eliberat de rigiditatea sălilor clasice.

Privit ca loc de întâlnire între arte şi creatori şi în final, între oameni și produsul artistic, teatrul devine o experiență comună. Bariera spaţiului constrângător, care limitează fără drept de apel cele două lumi, spectacol-spectator, se vrea a fi eliminată, astfel, se poate produce o legătură, o apropiere între cele două părţi esenţiale funcţionării spectacolului.

Dorinţele oamenilor de teatru în ceea ce priveşte arhitectura sălilor de spectacol, sunt expuse, într-un mod relevant în lucrarea lui Adolphe Appia Acteur, Espace, Lumiere, Peinture, apărută în 1920: "(...) noi vom ajunge mai devreme sau mai târziu la o sală, un fel de catedrală a viitorului, care într-un spaţiu vast, liber şi transformabil, va primi manifestaţiile cele mai diverse ale vieţii noastre sociale şi artistice şi va fi locul prin excelenţă unde arta dramatică va înflori, cu sau fără spectatori." (Appia 1920)

Încă din secolul XX, observăm dorinţa regizorilor spre spaţii flexibile, care să le ofere puterea de a crea liber, fără constrângeri spaţiale. Dacă teatrul tradiţional, nu le oferă astfel de spaţii, aceştia sunt dispuşi să mergă în căutarea expresiei dorite în afara sălii clasice a teatrului.

\section{Flexibilitatea spațiului teatral}

Arhiectura teatrelor, nu mai răspunde cerinţelor noului val de regizori. Evoluţia conceptului noului tip de spectacol, atrage după sine schimbarea spaţiului, spre unul dinamic, uşor transformabil pentru a oferi opţiuni variate.

"Arhitecţii şi-au dat seama că, dacă continuă să ignore realitatea, încetează sa mai existe. Motiv pentru care au început să facă concesii tehnicii şi exigenţelor societăţii, sau, mai degrabă să înţeleagă că frumuseţea nu constituie o valoare în arhitectură decât dacă aceasta este capabilă de a o pune în evidenţă servind nevoile vieţii într-o manieră perfect organizată din punct de vedere tehnic." (Arendt, 1997, coperta 4)

Desigur, ca şi în celelalte arte, conflictele legate de tradiţie şi experimental, apar şi în arhitectură, dar până la urmă acest vast domeniu este făcut să servească şi să vină în întâmpinarea funcțiunii pe care o deservește, asigurând cadrul optim.

Primele schimbări spațiale referitoare la sălile de teatru au apărut din dorinţa regizorilor de a crea apropierea spectatorului de spectacol. Acest desiderat conceptual al modului de abordare a spectacolului de teatru a atras după sine şi transformările scenice, adoptarea flexibilităţii spaţiului de joc, scena obținând astfel un suflu nou prin eliberarea barierei rampei şi oglinzii scenei.

O problemă care a preocupat mereu, este această limită ca loc de întâlnire al celor două entităţi, al celor două lumi realmente diferite, care trăiesc într-o relaţie simbiotică de mai bine de douăzeci şi cinci de secole. De la amfiteatrul grec cu limita clară, la teatrul de stradă medieval, trecând prin controversata Comedia dell'Arte, la teatrul spaniol renascentist, unde clasele privilegiate erau poftite pe scenă, şi ajungând până azi unde spectatorul face parte din actul creator, limita fizică se vrea a fi reprimată și de noile teorii regizorale.

În 1927, răspuns, la noile viziuni conceptuale, ale regizorilor, la Bauhaus, i-a naștere proiectul Teatrului Total al arhitectului Walter Gropius, un spațiu flexibil, dinamic, care alături de un sistem de proiecții devenea o adevărată maşinărie de teatru. 
Pentru Walter Gropius, “(...) teatrul este un centru de educaţie colectivă şi contribuie la rezolvarea contradicţiei dintre munca de masă şi existenţa individuală, reintegrând sensibilitatea < ştirbită > de munca mecanică, în procesele şi ritmurile sale, stabileşte un contact deplin cu realitatea şi satisfacerea instinctelor totale. Teatrul nu va mai fi o instruire moralistă sau o şcoală a sentimentelor, ci o educare integrală a sensibilităţii care are ca scop de a dezvolta, prin capacitate perceptivă, aptitudinea pentru organizarea şi construcţia rapidă a spaţiului." (Argan 1976, 133)

Teatrul Total, pune accent pe întreg spaţiu teatral, sala are o formă eliptică, semănând cu un ou imens tăiat în două. Flexibilitatea spaţiului, este dată de scena turnantă şi mobilă pe trei direcţii şi ale cărei practicabile se pot deplasa în jurul sălii. Avanscena, se poate ridica şi lăsa, iar primele rânduri de scaune se pot roti cu 180 de grade, transformându-se într-o arenă devenind astfel un spațiu total.

Deşi nerealizat, proiectul a devenit un model, un punct de plecare spre noile spaţii teatrale transformabile si adaptabile la noile viziuni regizorale.

Ca şi Gropius, constructiviştii ruşi se învârt în aceleaşi sfere conceptuale, ei văd în teatru un mod de a educa, de a duce omul într-o nouă dimensiune spirituală. Constructiviştii ruşi, cu precădere Konstantin Melnikov, propun împlicarea spectatorului într-un mod activ, ca parte din creaţie, ne mai fiind un simplu privitor.

Spaţiile create de Melnikov, într-un club muncitoresc din Rusia au un sistem flexibil de compartimentare, cele şase săli pot fi transformate într-una singură. Adoptă soluţii inovatoare, oferind asftel atmosfera optimă pentru diferite activităţi: educative, politice, culturale, apare ideea de spaţiu multifuncţional.

Teatrul experimental, văzut prin prisma spaţiilor, a sălilor flexibile, multifuncţionale, uşor transformabile şi adaptabile de la un tip de scenă la altul, (scenă elisabetană, scenă italiană, scenă tip arenă), poate avea rolul de a ţine publicul legat de teatrul clasic, de acel simbol arhitectural, dar totodată oferindu-le creatorilor de teatru multiple posibilităţi de exprimare a creaţiilor.

De-alungul istoriei, astfel de spaţii sunt găsite sub diferite nume: Sala atelier Sala studio, Sala experimentală. Ele au fost create în teatrele mari, care pe lângă Sala Mare, clasică şi dominantă au simţit nevoia să aibă în structura lor şi aceste mici săli alterative, din dorinţa de a nu pierde creaţiile avangardiste, care negăsind cadrul optim migrează spre spaţii neconvenţionale, aşa zise neteatrale.

Teatrul Municipal din Ulm, Germania, oferă o sală mică cu o capacitate de 200 locuri, sala Podium, creaţie a arhitectului Fritz Schafer şi a scenografului Thomas Munter. Aceştia proiectează sub scena mare o sală experimentală, flexibilă cu plan hexagonal, având un diametru de 18 m, şi putând fi transformată în sală clasică italiană, cu gradene, scenă şi cortină, în sală arenă, cu scenă centrală, sau elisabetană cu public pe trei laturi.

O altă sală trasformabilă este Sala Mică a teatrului din Dusseldorf, cu dimensiuni reduse, numărul spectatorilor diferă în funcţie de modul de amenajare de la 250 la 300 de locuri. Deşi are în componenţă o parte fixă centrală, flexibilitatea este dată de spaţiile laterale, mobile şi transformabile, dar şi de dinamismul pereţilor mobili, care pot fi dispuşi liber, oferind astfel scenografii spaţiale variate. 
Tot din dorinţa de a elibera spectacolul de constrângerile tradiţionale, arhitectul Bernard Guillaumot crează în Franţa proiectul pentru o sală adaptabilă la Vitry, având cu un plan hexagonal, delimitat de pereţi amovibili, ce despart circulaţia de incinta sălii. Atipic în acest nou spaţiu este dispunerea sa în plan vertical. Cele două galerii, prima,situată la $5.30 \mathrm{~m}$ de la sol, înconjoară sala pe două laturi asigurând accesul la cealaltă galerie suspendată, la $7.35 \mathrm{~m}$ de la sol. Aceste pasarele, care învăluie scena, sunt concepute ca o prelungire a spaţiului de joc, spectatori fiind în mijlocul actului artistic.

Tot în Statele Unite, în 1961, arhitecţii firmei Harry Weese \& Associates, realizează Teatrul Arena Stage din Washington. Sala are ca şi configuraţie, un plan central care împreună cu plafonul tehnic desfăşurat pe toată suprafaţa sălii, oferă numeroase tipuri de montări scenice.

În 1968, la noi în ţară, Liviu Ciulei, transformă un spaţiu tradiţional, într-o sală dinamică Sala Studio a teatrului Lucia Sturdza Bulandra. Spaţiul poate fi compus atât în scenă italiană, în scenă elisabetană cât şi în scenă arenă.

Cu doar câțiva ani în urmă, (2014) Teatrul Naţional din Bucureşti a fost inaugurat în noua s-a formă, având şapte săli, dintre care șase transformabile (Sala Mare, Sala Mică, Sala Studio, Sala Pictura,Sala Atelier, Sala în aer liber, Sala Media) devenind astfel o adevărata maşinărie de teatru, adaptându-se tendinţele actuale, din dorința de a pastra publicul legat de acest simbol cultural, teatrul.

\section{Teatrul neconvențional}

În ultimii ani, teatrul s-a schimbat, a luat o direcţie surprinzatoare. Teatrul burghez era în perfectă concordanţă cu funcţiile sale, iar clădirile de odinioară au supravieţuit, lăsându-ne astfel o moştenire zadarnică. În zilele noastre teatrele construite îndeplinesc rareori condiţiile necesare pentru ca viaţa să existe cu adevarat. Migrarea spre spaţii improvizate, constituie o alternativă pentru explorarea vieţii teatrale în adevaratul sens al cuvântului.

\section{Spații teatrale neconvenționale}

Spațiul scenic convenţional este contestat, apare teatrul experimental, ca manifest împotriva rigorii scenei naturaliste, modificând convenţiile tradiţionale de spaţiu, de circulaţie. Apare spațiul non-teatral, iar publicul este invitat să ia parte la acțiune. Printre primele apariţii de reprezentări într-un spațiu non-teatral sunt la New York, în 1979, când un grup de artiști au început să folosească fostele săli abandonate ale școlii "Public School 122" pentru spectacolele de teatru experimental. Astfel spectacolul de teatru sparge barierele clădirii cu fucțiunea clară de teatru. Apar tot mai multe abordări experimentale, unde creatorii exploatează încărcatura senzorială a spațiului transformandu-l într-un act artistic total.

În ultimi anii regizorii romani, încep să exploateze spațiile teatrale neconvenționale venind astfel în întâmpinarea publicului ce nu se regăsește în abordările clasice, tradiționale. Astfel un teatru viu ce emană și propagă emoția unui act artistic valoros reușește să ajungă în rândul publicului ce până azi nu frecventa sala de teatru.

Ramând în acestă sferă a teatrului experimental din Romania, putem aminti remarcabila punere în scenă a piesei Faust de Johann Wolfgang von Goethe regizată de Silviu Purcărete, care deschide noi orizonturi pentru spaţiul scenic. Fosta hală Simerom din Sibiu este amenajată 
mai întâi ca sală clasica tansformându-se ulterior în imaginea simbolică a iadului, loc în care este invitat şi publicul spectator să ia parte la impresionatul joc actoricesc, contopit cu elemente specifice circului, acrobaţie şi jonglerii cu focul.

O altă abordare neconvenționala a unui spectacol de teatru de data acesta din București este creația trupei Rampa din 2014, reușind sa creeze atmosfera din Azilul de noapte de Maximi Gorki într-o experiență inedită, având drept fundal spațial Hanul Solacalu. Abordarea experimentală înglobează spectatorii în actul artistic, spațiile de joc multiple de la curte la camerele de la etaj animate de actori oferă publicului un teatru viu, natural, necenzurat, ce are drept scop propagarea valorilor artistice, culturale în rândul unui public nou, ce nu se regăsește în sălile clasice de teatru.

\section{Teatrul de stradă}

O altă formă a teatrului neconvenţional, este teatrul de stradă, care s-a născut din dorinţa regizorilor de a fi cât mai aproape de spectatori, de a veni în întâmpinarea lor, de a se întâlni necontrolat cu publicul. Locurile de desfășurare sunt variate, de la parcuri, spaţii comerciale, parcări auto până la stațiile de metrou.

"Aceste iniţiative tind spre o deplină libertate a expresiei ideologice, care se poate atinge în afara oricărei organizări comerciale şi cel mai adesea în aer liber". (Pandolfi 1971, 407)

Câteva exemple ar fi: Mime Troup, San Francisco, care au creat o serie de spectacole inspirate din personajele Comediei dell Arte, la Minneapolis Firehouse Theatre au montat în aer liber piese de Megan Terry.

La noi în ţară "Teatrul Masca", înfiinţat în 1990 de către Mihai Mălaimare, a făcut pionierat în acest tip de abordare a spectacolului de teatru. Lipsa unui spaţiu construit i-a determinat să iasă în stradă, axându-se pe reprezentări de dans şi pantomimă. Cu o serie de mici spectacole în aer liber, în parcu pe stradă, precum: Liceeni, Statuile, Pardesiele, Beţivul, Romeo şi Julieta, etc., aceste abordări ne duc în zona performance, bazându-se pe un impact direct cu publicul. Textul lipseşte, accentul se pune doar pe puterea vizualului.

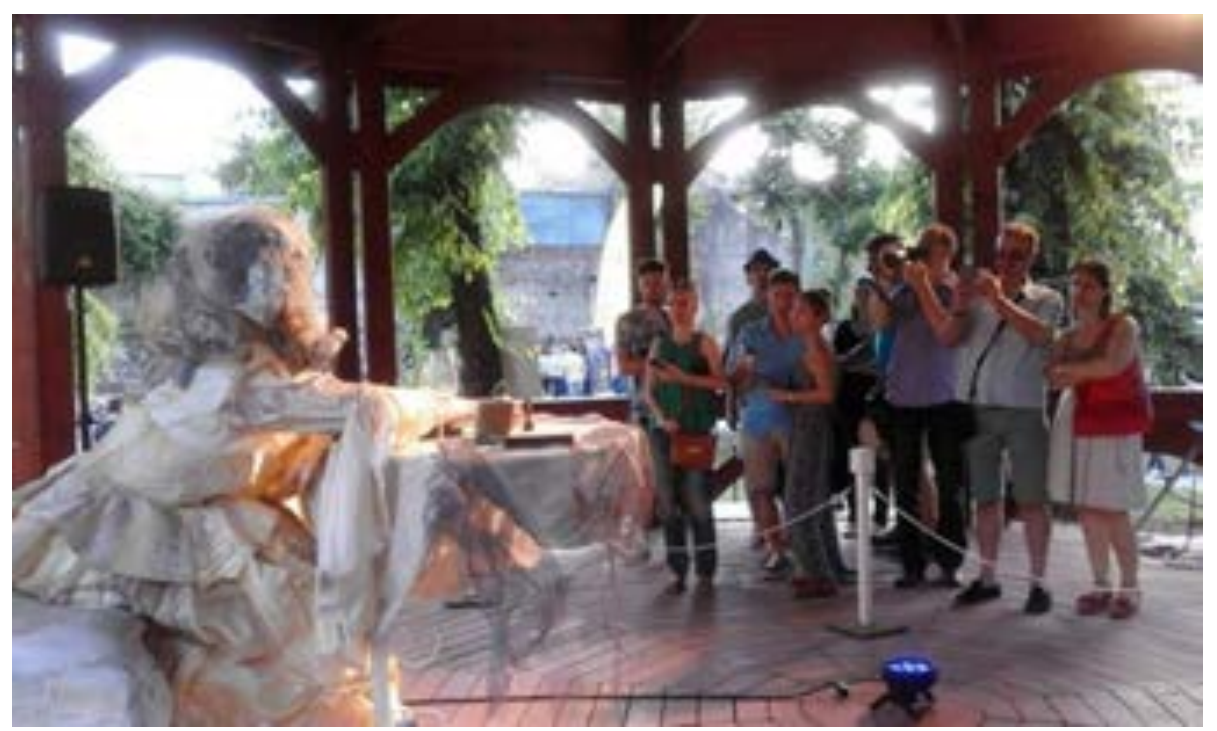

Fig. 1. Festivalul de statui vivante, București 2016, Curtea vilei Cesianu 
Din 2010 în Bucureşti se organizează festivalul de teatru de stradă B-FIT in the Street și Festivalul de statui vivante (Fig. 1) care animă şi cultivă un gust pentru astfel de reprezentări neconvenţionale, oferind publicului întâmplator posibilitatea de a lua contact cu teatrul.

Teatrul de stradă în contextual actual poate avea rol de promotor a valorilor culturale în rândul maselor, o manifestare mesager, un mijloc de propagare a artei și de ce nu de manipulare spre cizelarea gustului publicului spectator.

\section{Concluzii}

Aşa cum spune Peter Sellars. "Ceea ce-mi place în teatru e faptul că el nu se încheie niciodată. Continuăm mereu să lucrăm. (...) Lucrul nu e terminat niciodată, pentru că teatrul e întotdeuna un proces, niciodată un punct de sosire." (Toniza \& Banu 2004, 539).

Teatrul, ca organism viu, nu poate fi oprit şi canonizat, el are nevoie mereu de suflu nou, fiind într-un proces de transformare continuă. Rolul de simplu privitor este abolit. Un teatru viu emană emoţie, trăieşte împreună cu publicul său, nu doar pentru public. Tot mai des participăm la puneri în scenă ale unor opere clasice, dar într-o atmosferă nouă.

Spectacolul se schimbă și odată cu el şi spaţiul. Arhiectura clasică a teatrelor, nu mai corespunde cerinţelor noului val de regizori. Evoluţia conceptului de spectacol, atrage după sine schimbarea spaţiului, spre unul dinamic, uşor transformabil pentru a oferi opţiuni variate

Desacralizarea teatrului şi aducerea spectatorilor, în diferite spaţii urbane neteatrale, oferă creatorilor de teatru experimental, percepţii diferite, facându-i să viseze la noi forme de expresie. Astfel un teatru viu care se simte, se vede, se aude, având o semnificaţie cu precădere senzorială iși găsește puterea de a propaga valori artistice în contextul social actual.

Teatrul nu mai depinde de un loc anume, el poate fi reprezentat oriunde, pe stradă, în cafenele, în spaţii abandonate, tot ce contează este legătura dintre spectacol şi spectator, privitorul devine parte integrală a actului creator. Acest organism viu, "teatrul" caută mereu noi forme de expresie, este într-o permanentă mişcare, într-o continuă dorinţă de a surprinde, de a crea, de a experimenta noi senzații. Spaţiile neconvenţionale şi sălile flexibile, transformabile, devin atrăgătoare pentru regizori, oferindu-le cadrul optim pentru a-și elebora creaţiile.

\section{Referinţe}

Allain, P. J. (2006). Ghidul Routlege de Teatru și Performance. București: Nemira.

Appia, A. (1979). Acteur, Espace, Lumiere, Peinture. Espaces. Paris: Espaces.

Arendt, H. (1997). Intre trecut si viitor. Bucuresti: Antet.

Argan, G. C. (1976). Walter Gropius si Bauhaus-ul, Bucuresti: Meridiane.

Banu, G. (2011). Reformele teatrului în secolul reînoirii. Bucuresti: Nemira.

Banu G. (2016) Convorbiri teatrale- Festivalul internațional de teatru de la Sibiu. Bucuresti: Nemira.

Brook, P. (2014). Cu o prefaţă de Andrei Şerban, Spaţiul gol. Bucuresti: Nemira.

Brown, J. R.(2016). Istoria teatrului universal. Bucuresti: Nemira. 
Cheereau, P. (1970). L'espace institutionnalise. articol în L'Architecture d'aujourd'hui, octombrie noiembrie.

Grotowski, J. (1998). Spre un teatru sarac. Bucuresti: Unitext.

lotzu, Alexandru. (1981).Teatrul - act de creație arhitecturala. Bucuresti: Tehnică.

Ciulei, L. (2009) Cu gânduri și cu imagini. București: Igloo.

Pandolfi, V. (1971). Istoria teatrului universal. Vol IV. Bucureşti: Meridiane.

Saiu I. (2008). În cautarea spațiului pierdut. Bucuresti: Nemira. 


\title{
THEATRICAL PHENOMENON AS A CONTINUOUS TRANSFORMATION AND EXTENSION PROCESS ${ }^{1}$
}

PhD.c. arch. Silvia lonescu

University of Architecture and Urbanism „Ion Mincu”

silviaionescu29@yahoo.com

\begin{abstract}
The theatrical phenomenon has evolved continuously by adapting to the requirements of each historical period, being also a means of propagating its values.

In the current social context of perpetual change and adaptation to the new trends, the theatre plays a significant role in propagating conceptual desiderata, meant to be a model for a disoriented society always in search of identity. Nowadays, the role of a simple viewer is abolished, counting more and more on a living theatre that emits excitement, lives with his audience, not just for the audience.

The show changes and with it the space. The evolution of the show concept entails the change of space. By desecrating the theatre and bringing spectators into different non-theatrical urban spaces provides experimental theatre creators with new forms of expression. Thus, a living theatre that is felt, is seen, is heard, with a sensory significance in particular, finds its power to propagate artistic values in the current social context, being also a means of propagating its values.
\end{abstract}

Keywords: unconventional theater, theatrical spaces, alternative theatrical spaces, experimental theater

${ }^{1}$ Article from the PhD, unpublished: Unconventional theater, Connection, space, technology, show. Scientific coordinator: prof. PhD. arch. Emil Barbu Popescu 


\section{Introduction}

The show changes and with it the space. The classic architecture of theatres no longer meets the requirements of the new wave of directors. The evolution of the show concept, entails the change of space, toward a dynamic one, easily transformable in order to offer varied options.

Theatre, as a living organism, can not be stopped and canonized, it has evolved continuously by adapting to the requirements of each historical period, being also a means of propagating its values. The theatrical phenomenon seen as a symbiosis between architectural space and the show always needs a new breath, being in a perpetual process of transformation and expansion.

As Peter Sellars relates, the theatrical performance is an attribute of the present, having the power to influence the public to convey the current cultural values and desiderata to a disoriented society that is no longer identifiable, being rather attracted by the affordable, commercial entertainment. These are the current premises.

"The theatre has a sense of time, this is the present. This is the current moment, among us. It's the time I'm here, and you are there. It's a moment we can not repeat. It's always an accurate, precise moment. The theatre can only create the present. But interesting is that it talks about the past in the present." (Toniza 2004, 538)

Assuming these premises, the theatre created here and now adopts the new, unconventional breath, inoculated by the current visions of theatre creators, who wish to escape the rigidity of classical, conventional spaces and to penetrate into the everyday life of the audience.

By desecrating the theatre and bringing spectators into different non-theatrical urban spaces provides experimental theatre creators with different perceptions, making them dream about new forms of expression. Thus, a living theatre that is felt, is seen, is heard, with a sensory significance in particular, finds its power to propagate artistic values in the current social context.

Referring to the experimental theatrical phenomenon, it can not be treated and understood as a singular act, isolated by the whole, namely by the theatrical art in general and implicitly by the present society, eager to explore new experiences.

By limiting the discussion to the level of experimental theatrical art, the show can not be separated from space and vice versa, they have lived, evolved and reinvented together throughout history. Having as a premise this indestructible relationship, being a reflection of society, playing the role of propagating the values specific to each historical period and at the same time of manipulating, guiding the masses.

In the current social context of perpetual change and adaptation to the new breath, the theatre plays a significant role in propagating conceptual desiderata, meant to be a model for a disoriented society always in search for identity / balance. Nowadays, the role of a simple viewer is abolished, becoming more and more a living theatre that emits excitement, that lives with its audience, not just for the audience. 


\section{Evolution of the theatrical phenomenon in the XX-th centurie}

The image of the theatre we known is shaped in the eighteenth century. We can finally speak of the beginnings of modern direction, through the Meiningen School in Germany. The Meiningen Theatre gives up the conventional open stage, preferring the closed, realistic stage with an indoor frame. It also replaces two-dimensional painted decors with three-dimensional built-in decors in order for the illusion of reality to be more easily accepted by the spectator.

The twentieth century is tumultuous for the art of theatre, many directors are addressing new forms of expression for bringing always something new. Not less varied are the solutions given by the issue of setting up the stage, from broadly keeping the classic configuration type, the audience positioned in front of the stage, but with sensitive changes such as abolition of the footlights, the side forestage and the possibility of reducing the stage opening, looking for new stage structures to make a physical closure with the actor.

The beginning of the twentieth century brings changes in the perception of the theatre. It switches from the 19th-century mushy entertainment to the dramatic realism presenting the uncensored image of society. The young playwrights and directors migrate to alternative, improvised spaces where they can freely present their creations. The new theatre marked by the scenic realism and the transition from the painted decor to the one built is related to the establishment of Theatre Libre Company, coordinated by Andre Atoine, a supporter of scenic naturalism.

Naturalistic scenic approaches have been rapidly perpetuated across Europe. But the climax of scenic naturalism is reached by Konstantin Stanislavski, surprising the track of time, the environment denoted by the social status and including the smell, so the scenography reaches new sensory valences, a picture completed by the realism of the characters of Anton Cehov's dramaturgy.

A century of controversies of conceptual denial and rebirth, shortly the scenic naturalism is blamed, and the most radical exponents against the scenic image that reproduces photographic reality are Gordon Craig and Adolf Appia, who essentialize the theatrical art at both stage and directorial level. They abstract the decor by summing it up to a few architectural elements, steps, columns, a graphic game that is accentuated by the virulence of light.

The First World War transforms the theatre into a objectionable cry against propaganda. The climax of theatre performances aiming at being a protest is reached by the Dadaist Theatre with its representatives Tristan Tzara, Hugo Ball and Emmy Hennigs who founded in 1916, in Zurich, the Cabaret Voltare. Taking advantage of the neutral state of Switzerland, theatre stands out through violent and chaotic performances, where dance, poetry and music are simultaneously represented in a desperate cry against the horrors of war.

The image of society has always been reflected in theatre. The end of First World War brings slogans as the Theatre is a weapon, Vsevolod Meyerhold himself propagates the slogan Bring the October Revolution to the Theatre. Becoming a weapon, a way to essentialize the emotions of a nation, theatre becomes a modeling weapon of the masses.

Visually, scenographically, Vsevolod Meyerhold fully exposes the ideologies and symbolism of Russian deconstructivism. In his scenic approaches, he proposes an eviscerated space, destroys the stage frame and the proscenium by leaving out at sight the brick walls and proposes a 
scenography created from multi-level platforms, stairs, footlights, wheels, which are a support for the action space where the actor is transfigured in a bio-mechanical puppet.

World political agitation continues with World War II, bringing cooperation among independent theatres in Germany and Italy, which organizes small performances on the front to entertain troops.

Te end of War leaves scars, audience empathizes with mushy entertainment shows, musical performances, Broadway shows have been a great success. But the increasing cost of productions and subsidies granted to provincial theatres in the United States, England and Germany transforms spaces such as a Manchester-based cotton market in the Royal Theatre, which has an atypical structure, a glass cube sitting on four pillars. Another example is the Alley Theatre, which operates in a former fan factory in Hustan. So, the small troops migrate to altered spaces, attracting the audience.

The 70s bring the financial crisis among the theatres, which, although subsidized are confronted with the lack of audience, the delicate situation being amplified by the increasing costs of productions. In this unfavorable context, theatres in Europe host independent, experimental projects that manage to attract audience, a new theatre consumer eager to experience new forms of expression.

\section{The theatre space seen from the directors' perspective}

The theoretical and conceptual bases of the new theater are contoured, theoreticians and directors outline the image of the ideal theatre where they can show their creations without constraints.

Antonue Artaud sees the rebirth of theatre as being possible, by eliminating the conventionality of language, essentializing the show to a strictly visual form. He thinks that theatre has lost its attractiveness, the elites since can not find their provocative stimulus, give it up, and the masses seek immediate satisfactions, with an easy message, in accessible places such as the cinema, music-hall, or circus. His theories on the theatre art offer a credible, realistic, live, attractive show, where the audience "will believe in theatre's dreams." (Toniza $2004,304)$. He calls for a total show, which maximizes our sensory sensibility through sound, rhythm, image, merged into an unitary artistic act.

Starting from the total show, which has its roots on a shared art experience, the viewer, Jerzy Grotowski focused on his theoretical approaches on the spectacle-spectator relationship. He does not see the theatre as an immediate satisfaction of cultural needs, nor as an easy way of entertainment. Theatre is more, it is the privilege of the spectator whose "anxiety is not general, but directed in the sense of searching the truth about himself and about his vision in life." (Toniza 2004, 209). He is counting on a show which to emotionally and intellectually incite the spectator, an artistic act with an initiative role for its audience.

Still Grotowski talks about the theatre as a venue for creators and arts. His space concerns cross the boundaries of the show and come into the sphere of architecture, being concerned with the layout of the spectators' seats, only through a perfect symbiosis a truly moving and valuable act can be created. 
Peter Brook with his Empty Space work, shakes traditional theatre as both space and directorial approach. Counting on the brutal side of the theatre and considering that it can be done anywhere, on the street, in barns, in attics, everything that matters is the contact, interaction with the public, this force being defining for the art of the show.

"I can take any empty space and consider it a scene. A man crosses this empty space, and another is watching him and it's all a theatrical performance should have." (Brook 2014, preface)

Brook has the power to metamorphose any urban space whether public or private in a theatrical space, by counting on the transience of time and the architectural variety essentializes these two inseparable elements, space and show, in a total creative act encompassing a whole, viewer and creator. He meets the new audience constantly searching for the ideal space, for making it the frame of the new theatre freed from the rigidity of classical rooms.

As a meeting place between arts and creators, and finally, between people and the artistic product, the theatre becomes a common experience. The constraining space barrier, which limits beyond a reasonable doubt the two worlds, show-spectator, is supposed to be eliminated, thus, a connection, a closeness between the two essential parts of the show performance can be reached.

The desires of theatre people in terms of architecture of the auditoriums, are displayed, in a relevant way in the work of Adolphe Appia Acteur, Espace, Lumiere, Peinture, published in 1920: "(...) we will arrive sooner or later in a hall, a kind of cathedral of the future that, in a vast, free and transformable space, will receive the most diverse manifestations of our social and artistic life and will be the place where excellence will dramatically blossom, with or without viewers." (Appia 1920)

As early as the twentieth century, we note the directors' desire for flexible space, which gives them the power to create freely without space constraints. If the traditional theatre does not offer such spaces, they are willing to go looking for the desired expression outside the classical theatre.

\section{Flexibility of the theatre space}

The theatres' architecture, no longer meets the demands of the new wave of directors. The evolution of the concept of new type of show, entails the change of space, to a dynamic one, easily transformable in order to offer varied options.

"Architects have realized that if they continue to ignore reality, they cease to exist. The reason they began to make concessions to the technique and the exigencies of society or rather to understand that beauty is not a value in architecture unless it is able to highlight it by serving the needs of life in a perfectly organized technical manner." (Arendt 1997, cover 4)

Of course, as in the other arts, conflicts related to tradition and experimentation also arise in architecture, but ultimately this vast domain is made to serve and meet the functions it serves, providing the optimal framework.

The first spatial changes in the theatres came from the directors' desire to create the closeness of the spectator to the show. This conceptual desideratum of the way of approaching the 
theatre show has entailed the scenic transformations, adopting the flexibility of the playing space, the scene thus gaining a new breath by breaking the footlights barrier and the mirror of the scene.

An issue that has always been a concern, is this limit as a meeting place of the two entities, of the two truly different worlds, living in a symbiotic relationship for more than twenty-five centuries. From the Greek amphitheatre with the clear boundary, to the medieval street theatre, passing through the controversial Comedia dell'Arte, to the Renaissance Spanish Theatre, where the privileged classes were invited on the stage, and until today where the spectator is a part of the creative act, the physical boundary is supposed to be suppressed also by the new directorial theories.

In 1927, as a response to the new conceptual visions of the directors, at Bauhaus, the project of the Walter Gropius Architect's Total Theatre was born, a flexible, dynamic space, which together with a projection system became a real theatre machine.

For Walter Gropius, "(...) the theatre is a center of collective education and contributes to solving the contradiction between mass work and individual existence, reintegrating the < impaired > sensitivity of mechanical work into its processes and rhythms, establishes full contact with reality and satisfaction of total instincts. The theatre will no longer be a moralist education or a school of feelings, but an integral education of the sensitivity that aims to develop, through perceptual capacity, the ability to organize and construct space fast." (Argan 1976, 133)

Total Theatre places an emphasis on the entire theatre, the hall has an elliptical shape, resembling an immense egg cut in two. The flexibility of the space is given by the three-way revolving and movable stage, and its parallels move around the hall. The forestage can be raised and lowered, and the first rows of seats can rotate 180 degrees, turning into an arena thus becoming a total space.

Although not achieved, the project has become a model, a starting point toward the new theatre spaces transformable and adaptable to new directorial visions.

Like Gropius, Russian constructivists move in the same conceptual spheres, they see in the theatre a way of educating, bringing man into a new spiritual dimension. Russian constructivists, especially Konstantin Melnikov, are proposing to engage the spectator in an active way, as part of the creation, not being only a mere viewer.

The spaces created by Melnikov, in a working men's club in Russia, have a flexible partitioning system, the six halls can be transformed into one. It adopts innovative solutions, offering the optimum atmosphere for different activities: educational, political, cultural, the idea of multifunctional space appears.

The experimental theatre, seen from the perspective of flexible, multifunctional, easily transformable and adaptable halls from one type of stage to another (Elisabethan stage, Italian stage, arena stage), can serve to keep the audience connected with classical theatre, with that architectural symbol, but also by giving theatre creators multiple possibilities of expressing their works.

Throughout history, such spaces are found under different names: Workroom Hall, Studio Hall, Experimental Hall. They were created within the big theatres, which, besides the Great Hall, classical and dominant, felt the need to have in their structure these small alterative rooms 
also, in the desire not to lose the avant-garde creations which by not finding the optimal frame are migrating to unconventional spaces, the so called non-theatre sites.

The Municipal Theatre in UIm, Germany, offers a small room with a capacity of 200 seats, the Podium Hall, creation of the architect Fritz Schafer and the stage designer Thomas Munter. They project under the big stage an experimental, flexible hexagonal hall with a diameter of 18 $\mathrm{m}$, and which can be transformed into a classical Italian hall with stadium seating, a stage and curtains, with an arena hall with central or Elizabethan stage with audience on three sides.

Another transformable hall is the Small Hall of the Dusseldorf Theatre, with a small size, the number of viewers differs depending on the layout from 250 to 300 seats. Although it is composed of a fixed central part, the flexibility is given by the lateral, mobile and transformable spaces, but also by the dynamism of the mobile walls, which can be freely disposed, thus offering various spatial scenographies.

Still out of the desire to free the show from traditional constraints, the architect Bernard Guillaumot creates in France the project for an adaptable hall at Vitry, having a hexagonal plan, delimited by removable walls, separating the movement from the rest of the hall. Atypical in this new space is its arrangement in the vertical plane. The two galleries, first located $5.30 \mathrm{~m}$ from the ground, surrounds the room on two walkways providing access to the other suspended gallery, at $7.35 \mathrm{~m}$ from the ground. These walkways, which envelop the stage, are conceived as an extension of the playing space, with viewers in the middle of the artistic act.

Still in the United States, in 1961, architects at Harry Weese \& Associates, are building the Arena Stage Theatre in Washington. The hall has, as a configuration, a central plan that, along with the technical ceiling all over the hall, offers many types of settings.

In 1968, in our country, Liviu Ciulei transforms a traditional space into a dynamic hall, the Studio Hall of the Lucia Sturdza Bulandra Theatre. The space can be composed both in Italian stage, in Elisabetan stage and in stage arena.

Just a few years ago, (2014) the Bucharest National Theatre was inaugurated in its new shape, having seven halls, six of which are transformable (the Great Hall, Small Hall, Studio Hall, Painting Hall, Workroom Hall, Outdoor Hall, Media Hall), thus becoming a true theatre machine, adapting to current trends, out of the desire to keep the audience connected with this culture symbol, the theatre.

\section{Unconventional theater}

In recent years, the theater has changed, it has taken a surprising direction. The bourgeois theater was in perfect harmony with its functions, and the former buildings survived, leaving us a vain inheritance. Nowadays theaters rarely meet the necessary conditions for life to really exist. Migration to improvised spaces is an alternative to exploring the theatrical life in the true sense.

\section{Unconventional theatrical spaces}

The conventional scenic space is challenged, the experimental theater appears as a manifest against the rigor of the naturalistic scene, altering the traditional conventions of space and 
movement. Non-theater space appears, and the public is invited to take part in the action. Among the first appearance in a non-theater scenes take part in New York in 1979 when a group of artists began using the former abandoned rooms of "Public School 122" for experimental theater performances. Thus, the theater show breaks the barrier of the building with clear theater fiction. More and more experimental approaches appear, where creators exploit the sensory load of space, transforming it into an all-embracing artistic act.

In recent years, Romanian directors have begun to exploit unconventional theatrical spaces, thus appealing to the public, which is not found in classical, traditional approaches. Thus, a living theater that emanates and propagates the emotion of a valuable artistic act succeeds in reaching out to the public, which until today does not frequented the theater.

Remaining in this sphere of experimental theater in Romania, we can recall the remarkable staging of Faust by Johann Wolfgang von Goethe directed by Silviu Purcarete, which opens new horizons for the scenic space. The former Simerom hall in Sibiu is first arranged as a classroom later transforming into the symbolic image of hell, in wich the audience is invited to take part in the impressive actor's play, merged with circus-specific elements, acrobatics and fire juggles.

Another unconventional approach to a theater show this time in Bucharest is the creation of the Rampa band in 2014, managing to create the atmosphere of the Maximilian Gorki's Night asylum in an unprecedented experience, having as a background Solacalu Hall. The experimental approach encompasses the audience in the artistic act, the multiple playgrounds from the courtyard to the animated actors' floor rooms offer the audience a living, natural, uncensored theater that aims to propagate artistic, cultural values among a new audience that does not rezonate in classical theaters.

\section{Street Theater}

Another form of unconventional theater is the street theater, which was born out of the directors' desire to be as close as possible to the audience, to meet them, to meet uncontrollably with the audience. The venues are varied, ranging from parks, commercial spaces, car parks to subway stations.

"These initiatives aim at full freedom of ideological expression, which can be achieved outside any trade organization and most often in the open air." (Pandolfi 1971, 407)

Some examples are: Mime Troup, San Francisco, who created a series of inspiration from the characters of Comedy dell Arte, at the Minneapolis Firehouse Theater, featuring outdoor parts by Megan Terry.

In our country "Masca Theater", founded in 1990 by Mihai Mălaimare, pioneered this type of theater performance. The lack of a performing space led them out into the street, focusing on dance and pantomime representations. With a series of small outdoor shows, such as Liceens, Statues, Pardesiles, Swan, Romeo and Juliet, etc., these approaches take us to the performance area, relying on a direct impact with the public. The text is missing, the focus is only on the power of the visual.

From 2010 in Bucharest, the B-FIT in the Street Theater Festival and the Living Statue Festival (Fig. 1) are organized to animate and cultivate a taste for such unconventional representations, giving the public the chance to get in touch with the theater. 


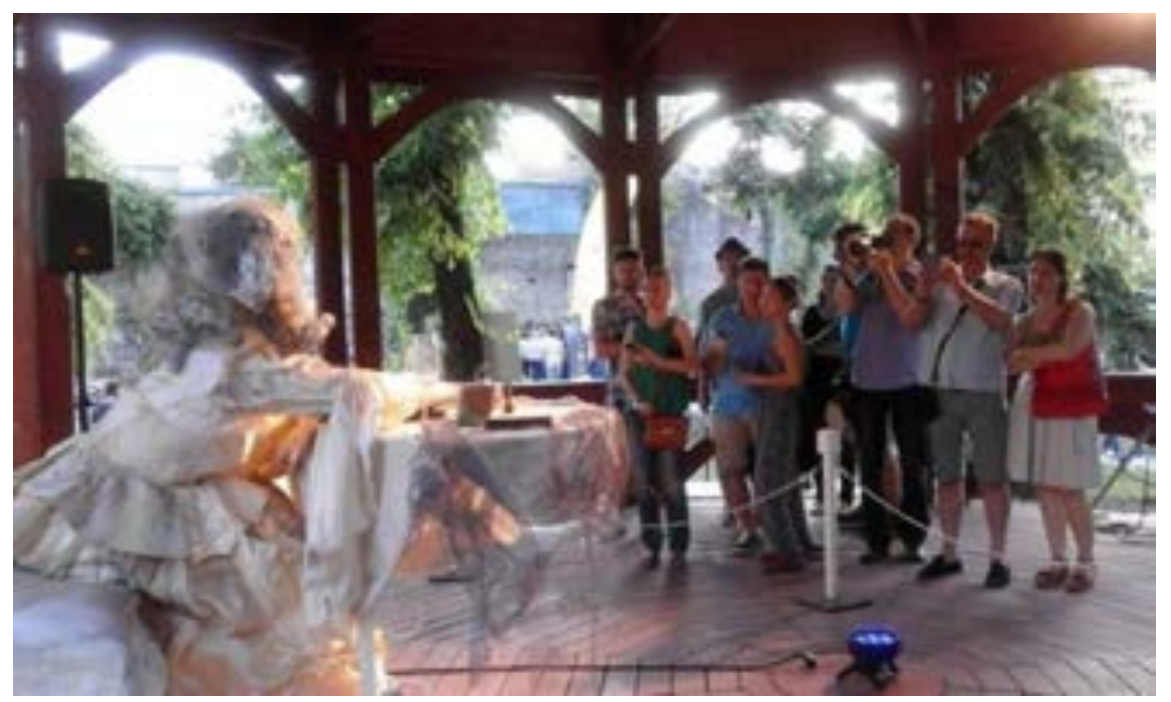

Fig. 1. The Festival of Living Statues, Bucharest 2016, Court of the villa Cesianu

Contemporary street theater can act as a promoter of cultural values among the masses, a messenger manifestation, a means of propagating art and why not manipulating the taste of the spectator.

\section{Conclusions}

As Peter Sellars says. "What I like in the theatre is that it never ends. We always keep working. (...) Work is never over, because theatre is always a process, never a point of arrival" (Toniza \& Banu 2004, 539).

The theatre, as a living organism, can not be stopped and canonized, it always needs new breath, being in a process of continuous transformation. The simple viewer role is abolished. A live theatre emits excitement, lives with his audience, not just for the audience. More and more often we participate in stage adaptations of classical works, but in a new atmosphere.

The show changes and with it the space. The classic architecture of theatres no longer meets the requirements of the new wave of directors. The evolution of the show concept entails the change of space, toward a dynamic one, easily transformable in order to offer varied options.

By desecrating the theatre and bringing spectators into different non-theatrical urban spaces provides experimental theatre creators with different perceptions, making them dream about new forms of expression. Thus, a living theatre that is felt, is seen, is heard, with a sensory significance in particular, finds its power to propagate artistic values in the current social context.

The theatre no longer depends on a particular place, it can be represented anywhere, on the street, in cafes, in abandoned spaces, all that matters is the connection between the show and the spectator, the viewer becomes an integral part of the creative act. This living organism, "the theatre", is always looking for new forms of expression, is in a permanent movement, in a constant desire to surprise, to create, to experience new sensations. Unconventional spaces and flexible, transformable halls are appealing to directors, giving them the optimal framework to develop their creations. 


\section{References}

Allain, P. J. (2006). Ghidul Routlege de Teatru și Performance. București: Nemira.

Appia, A. (1979). Acteur, Espace, Lumiere, Peinture. Espaces. Paris: Espaces.

Arendt, H. (1997). Intre trecut si viitor. Bucuresti: Antet.

Argan, G. C. (1976). Walter Gropius si Bauhaus-ul, Bucuresti: Meridiane.

Banu, G. (2011). Reformele teatrului în secolul reînoirii. Bucuresti: Nemira.

Banu G. (2016) Convorbiri teatrale- Festivalul internațional de teatru de la Sibiu. Bucuresti: Nemira.

Brook, P. (2014). Cu o prefaţă de Andrei Şerban, Spaţiul gol. Bucuresti: Nemira.

Brown, J. R.(2016). Istoria teatrului universal. Bucuresti: Nemira.

Cheereau, P. (1970). L'espace institutionnalise. articol în L'Architecture d'aujourd'hui, octombrie noiembrie.

Grotowski, J. (1998). Spre un teatru sarac. Bucuresti: Unitext.

lotzu, Alexandru. (1981). Teatrul - act de creație arhitecturala. Bucuresti: Tehnică.

Ciulei, L. (2009) Cu gânduri și cu imagini. București: Igloo.

Pandolfi, V. (1971). Istoria teatrului universal. Vol IV. Bucureşti: Meridiane.

Saiu I. (2008). În cautarea spațiului pierdut. Bucuresti: Nemira. 